\title{
Pondering about Animation Education in College
}

\author{
Xingqi Wang \\ Department of Animation School, Hebei Institute of Fine Art ,Shijiazhuang Hebei, 050700, China
}

\begin{abstract}
Keywords: Anime Education; Special Education; Education Brand
\end{abstract}
\begin{abstract}
This article promote the domestic animation education through the animation industry under the present situation, puts forward and concentrated on the presence anime education professional, homogeneity, the one-sided understanding of animation language, lack of authority compile for universal use of textbooks, teachers lack of several major problems, the enterprise differentiation, the changing concept, optimize professional teaching materials, establish national qualifications is what we discussed.
\end{abstract}

\section{Introduction}

A large number of Chinese teenagers watch cartoons, America, Japan and China invaded by economic and cultural invasion at the same time, under the reality of national ideology made the necessary adjustments. In politics and cultural creative industry from traditional manufacturing under the impetus of the transformation of economic structure, lead to the emergence of Chinese cartoon hot Chinese animation industry rapid development, animation education caused by the temperature, then the animation education problem is becoming more and more obvious.

\section{The Animation Industry Development under the Current Situation of Animation Education}

Development Situation. Animation Professional Animation and Digital Media Heat Generated Animation Professional. Animation is a combination of art and technology, and for 2D animation, $3 \mathrm{D}$ animation, and the application of network animation direction is different, animation education professional direction set differences. It is because of animation education across two characteristics in the field of art and technology, make the most of the colleges and universities in animation education possible. This includes the arts colleges and universities and engineering colleges, such as the academy of fine arts, science and technology institute, school of media, teachers college, institute of vocational education, etc. At present colleges for professional name not standardized, and so on various professional animation. Such as: animation, animation art, animation technology, digital animation, film and television animation, game animation and cartoon art, etc. [1] Most colleges and universities of professional animation based on 4 years, academic foundation weak, the animation teaching in the attempt stage, not cultivate high-level animation talents of software and hardware conditions. In recent years, animation and digital media hot tide swept across China. Animation related professional students after graduation can be engaged in film and television production, advertising, animation, building travel animation, animation publishing, multimedia design, network game, network, etc. Therefore, animation professional favoured by the broad masses of students to enter oneself for an examination the number increased year by year, some colleges and universities enrollment ratio nearly $1: 1$.

The Animation Professional Relatively Concentrated in the Economic Developed Areas. According to statistics, the animation professional schools are mainly distributed in Beijing, Shanghai, Guangdong, Zhejiang, Hangzhou and other places. National animation education base and animation industry base in Beijing, Shanghai, Zhejiang, Hunan, Guangdong and other places. 
Root cause lies in the fact that the eastern region economy developed, has brought higher consumption culture and film and more job opportunities, or more corresponding animation professional schools. Animation professional large-scale open, a lot of animation talent into the market, as well as other industries, new graduate animation talent must go through the inspection and selection of the market. The present students mostly not graduated from colleges or graduate from college, animation education achievement and efficiency will be gradually clear in the coming years. After the animation education standardization, large and small schools and its professional will experience to the integration of the animation.

Professional Training Objectives and the Creation of the Cartoon, Making Talent not Related. The Real National Animation Author are Rare. Cartoon talents knowledge structure including at least five aspects: basic theory, graphic design, animation, film and television playwright-director, animation and digital technology application. Throughout the colleges and universities all over the country, and have the ability to complete five aspects in the teaching of colleges and universities account for only a small part. Targeted to develop traditional animation creation, production personnel, such as animation scriptwriter, director, the original animation, especially, the design draft drawing personnel of colleges and universities and professional almost none. From this point, most is not what we call the animation specialty in the traditional sense of the animation specialty, but involves network, film and television advertising, 3D digital design professional design or digital film and television production.

The Setup of the Institutions for the Understanding of Animation. Animation professional generally belongs to the art department, design department, or computer system, also some belonging to engineering department or media. Colleges for animation professional teaching idea and course configuration for teaching resources of colleges have very big difference. Has strong academic basis of colleges and universities of technology, there are a large number of teaching resources and the basis of deep research. Animation professionals, in a such a college computer application class course is more, pay attention to the basic computer, software development and application ability of students training. Training direction is skilled talents. Arts foundation strong institutions, such as academy of fine arts or design institute, the opening animation professional, arts curriculum is more, pay attention to training students' art foundation and visual performance ability. Students to systematically study art foundation, the design idea, improve the aesthetic ability and art appreciation ability, cultivating direction is artistic creation talented person. Also some colleges simply divides into the animation technology and animation art two direction develop.

The Serious Lack of Professional Teachers, Professional Discipline Foundation is Weak. Professional Teaching Sources. It is estimated that 2004 years ago, the country has a master degree in animation in less than 10 people, and part is the study of animation theory. So today, start animation professional colleges and universities nationwide blossom everywhere, its animation professional teachers come from? Colleges generally adopt two methods to enrich the teacher. One is to send the school teachers to animation training education has a long history of colleges, such as the Beijing film academy. 2 it is direct hire animation, television practitioners as a full-time or part-time teachers. Two kinds of methods to solve some of the school at that time, but for education itself, there are drawbacks in one of two ways. Animation specialty in some colleges don't have the teachers, funds, equipment under the condition of $\backslash$ "horsel" in a hurry, first year students learn base class, such as sketch, color, composition of the big three, academic, etc. During this time finally to send young teachers to training or production unit. A year later, the teacher training completion, reluctantly, to go back to school on the platform, directly involved in the second year of the animation specialty teaching. Whatever young teachers' level of business and mastery of new 
knowledge, this way is in violation of the law of education teaching. [2]Hiring have certain experience in animation and television personnel, can temporarily solve the problem of professional teachers lack of animation. But most of these practitioners without teaching ability training, and the depth of the different understanding of the animation. And the senior professionals often cannot as full-time teacher in class. Schools and stable teaching staff and academic atmosphere will not set up in a short time.

\section{The Understanding of Animation is Insufficient, the Teaching Quality is Worrying.} Investigation of colleges animation teachers learn, have a plenty of don't understand art play areas and the creation of computer class teacher teach animation software; Have a plenty of the art of modern electronic technology to understand the superficial teachers' self-study of several animation software, I"learn now sell now. These teachers, in general, not in the field of animation made certain theoretical research and practical training. The cognition of animation in the surface layer, affect the college course Settings. Specific performance in: some universities simply understood as the original animation or animation $3 \mathrm{~d}$ software applications; Some universities confused difference of cartoon and animation, all called animation. Although open animation specialty, but few on behalf of the school theory and creative achievements in the field of animation, lead to the weak students knowledge, or the lack of the theoretical level, or the actual beginning ability is poor. School teaching concept of fuzzy, must cause the students' knowledge structure. There are many students reflect, in the animation specialty, to learn the painting, cartoon, animation, $3 \mathrm{~d}$ software, software, web design, graphic design, synthesis, etc., looks rich in content, actually tasted. Students did not learn can make a real deal is being pushed into the society, so there are often technical knowledge aging after graduation, actual combat experience, and other issues. A lot of people in childhood had flip book: each piece of paper draw a villain, action of each are not identical, when quick flip, feeling screen villain to move, this is animation of the original form. 20 years of the 20th century to the end of the 1930s end, when the father of the commercial animation film Disney will then "animation" new things that developed into a art, animation began to have many authors and audience, million Disney cartoons and our country animation originator's three brothers "havoc in heaven" and other works can be said is known. These works using traditional animation method, namely each picture are actually by animators in the two-dimensional plane by hand drawing and. So why is the static image can give people the feeling of dynamic? Animation and film and television are the same as a technology and produced by the characteristics of human visual persistence. The so-called visual persistence, is refers to the people's eyes in more than 24 / s picture playback speed can not be distinguished. Each individual static images. Higher speed will make the action look smoother and more continuous. When the speed is slow, the picture will have a beat or flicker. Animation is to play a series of static images quickly, so that people have a dynamic effect on the visual. Composition of animation per a static picture called "frame", animation playback speed is often referred to as a "frame rate", expressed in per second play frames, denoted by F / S. The early animation works made by hand painted, the production process is complex, the production cycle is long, the expression is very limited. Computer graphics technology emerged organically high-tech and artistic creation, the 2D computer animation production system (such as the animator animation production system), using computer processing characteristics, the large number of repetitive labor by a computer to do, greatly reduces the complexity of the production process, improve the animation production efficiency. In the two-dimensional animation production system has also increased the number of animation and animation effects, and some results are not complete by hand drawing. But it is difficult to show the real life of people and things, not to say the imaginary world of the artist's imagination. With the improvement of computer technology, 
computer three-dimensional animation production system came into being. Three dimensional animation system perfectly will computer technology and art combine, not only for the artists provides unprecedented creation tools, and thoroughly to extricate them from brushes, canvas. Artists only need to use a variety of tools available on the computer to make their own creativity and imagination.

Animation there were Significant Differences in the Curriculum, Cultivate Diversified Direction. The "animation" is not only refers to the animation in the traditional sense, is a completely new concept. It which has very broad, such as $2 \mathrm{~d}$ animation, $3 \mathrm{~d}$ animation, multimedia, network, animation, film and television animation stunt, game software, cartoon creation, etc., all belong to category of animation. So the training goal, professional must refine, it forms the diversified characteristics of animation education at present. The institutions according to market demand and our advantages, set up various animation professional (or professional direction), professional curriculum has bigger difference. By randomly selected 8 and 8 art colleges and universities in science and engineering colleges, analyzes its animation professional curriculum, we get the following results: (1) the animation in a engineering college professional towards digital technology application. Based on the resource advantage of our school, basic computer, computer graphics, C language program design, multimedia technology, audio technology courses appear in the school curriculum, the highest for 14 class. (2) the art college of animation professional painting, design ability training is emphasized. Introduction to art, introduction to communication, Chinese and foreign art history, the three major composition, art psychology courses appear in the school curriculum. (3) some college course name not clear problem. Some of the colleges and universities of course name ambiguous, curriculum content. For example: the media and publishing, visual representation, overview of scenario planning, planning and scheduling, cartoon, etc.

The causes of the above conditions are: (1) due to the lack of teachers, some colleges and universities is no animation motion law, professor of film language teacher, so can only be focused towards computer application, or art, graphic design direction. (2) depend on the resource advantage of, on the basis of the original teaching facilities and faculty, rushed building after a certain improvement and integration. Especially the education of computer animation, graphics, the application of new media technology and computer technology, the subject is the strength of science and engineering college. (3) teaching hardware cost reduction. With the development of computer technology, hardware cost needed for the animation education decline year by year. 2000 years ago a qualified for the requirements of making the three dimensional animation basic PC in $1130(0$ Yuan, now has fallen to 5000 Yuan, with superior performance. [3]

Different Animation Professional Graduates Employment Direction of the Shunt. China's animation industry there is a huge market potential and the personal development space. Students to choice, development potential is big, good salary and conditions; Unit of choose and employ persons to student's choice, is the business ability and reasonable salary requirements etc. But colleges and universities graduate students, have high expectations of salary, hope engaged in high technical content or creative, and the business ability is weaker, leads to the contradiction between supply and demand both sides always exist. This contradiction reveals the education and practice disjointed phenomenon, this is also a problem to be solved in animation education.

Animation professional graduates in the traditional two-dimensional animation original animation creation of jobs. A qualified original painter must exercise after two years of actual production. Common course during the period of school and colleges and universities graduates to study culture, art theory, ideological education, and social investigation, graduation requirements, so they may not have the original animation to train a lot of time. When the painter, as soon as she 
graduated, of course, it's hard to even at the bottom of the need to adapt to a period of time. Mid the animation is labor intensive, need a lot of manpower engaged in painting, stroke, type, color, etc., a line of animation personnel are generally not direct mount guard after training, the training has very strong pertinence, learning purpose, they could have room to finish the original animation drawing or use animation software, but in the aesthetic, artistic creation and art appreciation ability is weak. From this perspective, a four-year animation professional graduate proficiency in the original miss a four years study in animation original painting is logical. Is accepted by the college students creative ability and aesthetic appreciation ability education, only in the later further study and creation. [4]

Engaged in the computer animation slightly lower to the requirement of the fine arts foundation, is bigger than traditional two-dimensional animation scope of employment. Although the graduates of colleges and universities has more than ten thousand people a year, but can enter the animation accounts for only around $20 \%$, mostly to advertising, games, Internet, television, press and animation teaching jobs. Compared with in $2 \mathrm{~d}$ animation original animation, college graduates are more likely to enter industry is advertising, web sites, games, cartoons, web design, web animation, etc. Industry and the current domestic network game industry's market size is bigger than the animation industry, also need a lot of animation talent. And some of the film and television, web sites, game production unit say they are hiring right now, don't even look at where applicants is graduate, what degree, as long as you can immediately make a decent thing, immediately. It also easy to find, cause computer animation talents facts of relatively high wages.

\section{The Problems Existing in the Domestic Animation Education}

Currently anime education from the scale of production to the production scale of the problems existing in the development of the main reason lies in the following aspects:

Professional Setting is too Concentrated. Mainly embodied in the curriculum mainly in the production link, which is drawing and animation. Planning, creative writers, while the rest of the animation production management, marketing promotion, copyright agent, derivative product development, and so on professional very lack, lead to the rupture of the animation industry chain, to cultivate the students can't meet the demand of the market, and now the whole talent cultivation in both excess and deficiency.

A single animation specialty, is not only makes the animation talents both excess and deficiency, affect the development of our animation industry at the same time, at the same time bring us animation education itself is concentrated in a certain professional aspects of the malignant competition.

Enterprise Homogeneity. Animation industry is its profit after the industry chain is running, each link of the profit, rather than a profit. According to international practice it on broadcast link just pay $10 \%$ to $15 \%$, completely recover the costs and profits is inside the other links. Only after work, can the real profit. Now a lot of animation is just making enterprise, company has no other links, resulting in the industrial chain of fracture. This is also lead to the cultivation of the talent in both the main reason for the excess and deficiency. Performance in the industry itself exists only attach importance to make and do not take the other part of state, is the enterprise homogeneity. Result of homogenous enterprises produced push out of our products.

The One-sided Understanding of Animation Language. Thought with the film and television animation is similar or even the same, and then think of the film and television some corresponding professional can replace corresponding professional animation, many colleges and universities put animation director and screenwriter professional animation are in college or department of literature, 
film and television art.

Think the animation is the film and television, is it related to the film and television animation, but it is an independent category of art. In addition to the film and television audio-visual language system, it also has a specific, what film does not have only some a cartoon animation language expression system. Is a difference in the independent film and television arts.

With film and television animation have the same place, but also has the very big difference, such as: spongebob squarepants with octopus strike, leave of that paragraph, the octopus lie prone on the glass sponge baby away, first hand in the above, the second open eyes on it, the third open heart on it. A situation in the heart of this through body dismembered shows, movies and television do not have this kind of expression is animation unique language system, it can be better than the actor's performance, more fully the performance of the character's inner world. Can also through the object color, shape transform to express emotion. Like spongebob squarepants lie prone on the glass when the facial expression, color and shape is not the same as usual, all changed. By turns out to be yellow change into a dark color.

Cartoon language system but also in many ways, such as the abstraction of the concrete. The embodiment of abstract and so on, there are a lot of specific language elements. But at present, the animation industry, animation industry to the problem or didn't notice, or is not enough attention. The animation for film and television, or as with film and TV the same things, same type of art creation. The pursuit of too much similar with reality, movement similar, similar expressions. This is also lead to most of the domestic animation not good-looking, low ratings can't really win the audience's recognition and welcome in the core of the reason. Story question is one reason, but the core problem is the animation language, on the application of animation unique ways, in fact the real animation works, its characteristic is that it is not similar with film and television, rather than on the similar. Film and television not the subject of performance is the theme of animation performance, film and television can't performance way, is the expression animation.

Lack of Authority Compile for Universal Use. Now in the market about animation teaching material more focused on the production, the application of the software or the modeling, the production process. And a lot of similar professional teaching material itself is just before a transformation, come to it from other professional makeover, didn't really show production, animation education of professional characteristics.

Such as animation creative planning, animation writer, animation director, or late animation derivative product development, or marketing, the copyright of the proxy class education books rarely, some even no. And we see only, change teaching material is also about anime writers from film and TV writers. Anime itself, it has its specific language system, the language system must from the animation creative and planning the writers used inside, not until the director added. Just like our film writers must have a lens flu, it is not a literary creation, it is a kind of film creation. Anime writers and it is not same the creation of the film or TV play creation, should be the creation of the cartoon. But now, this kind of teaching material, is there, also from the professional turned to other. So it is hard to make our animation specialty teaching real professional. Which compile for universal use of the lack of teaching materials, even no normative, the standardization of the teaching material is the lack of students, of course, can't be regular professional training.

Lack of Teachers. Now the country so much animation specialty, in university start a very serious problem is the problem of teachers. The faculty is not only a number of problems, and teachers' professional accumulation of itself. Computer teachers or teachers of fine arts animation in specialized course teaching pattern is so common in the fine arts, computer, was associated with anime, but still a difference. [5] Understand art does not necessarily understand anime, understand 
the computer more don't understand the animation. So, in the case of a serious shortage of teachers, is not only difficult to open the anime industrial chain each link needed professionals, it is hard to cultivate real qualified animation talent.

\section{Animation Education Problems Existing in the Solution}

The Specialties of Differentiation. Specialties of differentiation rather than homogeneous because the animation is made up of many links at the same time a industrial chain and the colleges and universities don't focus on the professional set on a certain link. Each school can according to their own characteristics and advantages, select set corresponding professional, cultivation of animation industry chain on a particular link. Only in this way can form a complementary between schools, rather than a homogeneous competition.

School because of involving anime professional distribution in different colleges, schools can overall management and planning, achieve the resources reasonable use, computer, literature, economic management, industrial design, different departments, such as anime related professional can be combined with the animation specialty establishment, film and television, animation director, animation marketing, animation derivative product development and other related professional, such as:

Of Chinese literature through literary language and cartoon language training, focus on the talent of education planning and screenwriter. In school of economics, through the marketing of animation with the ordinary marketing research of universality and individuality, cultivate cartoon marketing talents, etc.

The Enterprise Differentiation. Only differentiation can fully meet our whole animation industry chain each link on the demand for talent, rather than just focusing on one aspect. Such as animation talent surplus now, writers, directors, and animation film management, marketing promotion, derivative product development personnel and the problem of insufficient. So this respect everyone a lot of competition, and doesn't have the talent, and then another direction leads to animation industry talents both surplus and deficit.

So be sure to make full use of various colleges and universities of its own advantages. Such as journalism and communication, journalism. It also opened this major of Beijing sports university, Shanghai university of finance and economics also open this professional. But Beijing sports university training is a sports journalist, university of finance and economics training is a financial journalist. So he has the method of combining with major, to avoid conflict with the news talents with comprehensive professional colleges and universities. It is unique, others can't compete. This needs to make the necessary research, take corresponding measures, to talented person's raise.

The Idea of Change. Industrial chain fracture cause at the same time, enterprises simplification, homogeneity and cause a misunderstanding, make our animation education, animation talent cultivation, also think animation talent demand is talented person's demand, such an idea, in turn it will affect the animation specialty setting. Screenwriter, director and animation talents lack and affect the animation company, said in his creation, now a lot of animation enterprise planning, writer or a director, he went to children's literature writer, or a film and television screenwriter, director, creation or film director. In fact, they don't grasp that some designers animation language, this is the problem brought by the enterprise itself anime education problems.

Our animation industry hasn't actually, mastered the talented person of all media, so the school learn film, not only learn the film, also should have related technologies. Related to anime also will not only draw cartoon, the media also can learn knowledge.

At the same time, we should not only cultivate creative talents, to cultivate more understand the 
art of business talents, can have the ability to communicate in English. Only in this way, our animation industry to good work.

Optimize the Professional Teaching Materials. To select a batch of excellent foreign translation of professional teaching materials, reference and learning. Then on this basis, combining with our national conditions, and published the national animation professional compile for universal use textbooks, to standardize the animation specialty teaching. Can't be a similar professional teaching materials, should be combined with characteristics of animation specialty for real conform to compile for universal use of the animation specialty teaching material compile for universal use.

To Establish National Qualifications Training Bases. Our training is not only is an artist, but also can cultivate the ability to create professional, have to sell the goods, can survive in the industry. Professionals are professionals or experts to develop, if not the professionals in the industry, cultivate professional talents in this field, so the use of high quality teachers both at home and abroad, the first line of training professional talents and professional experts domestic animation specialty teachers in colleges and universities, the construction of qualified teachers are the effective measures to solve the problem of animation teachers now.

\section{Circumstances of the Development of Chinese Animation Education}

Investigation, Research and Positioning. On comprehensive understanding of China's animation industry, through the construction situation of each region, contains the curriculum status, long-term employment situation, investigation and study, combined with the actual situation of different regions, different schools of animation professional feature localization.

The Characteristic Education. In animation based on the cultivation of professional talents for the characteristic education road, namely, to establish anime education brand, set up special courses, choose the characteristics of teachers, characteristics of teaching content, teaching method, characteristic and characteristic teaching management, construct characteristic specialty, build characteristic education environment, carries on the characteristic of teaching, the characteristics of talent cultivation.

In a word, the development of animation industry is the key to personnel training, and can fully meet the demand of industry personnel training needs to establish an professional, animation industry and anime education should promote each other, and to restrict each other. There are two ways you can choose to use animation in a multimedia project. One is to use a special animation software to generate independent animation files. The animation files can be embedded into a multimedia project, and can also be used to control the playback of the program. Animation produced by the use of animation software frame based animation, animation based on the role of animation and object based animation. The other is to use the multimedia creation tool to provide the animation function, the production of simple object animation. For example, you can make an object on the screen (can be a picture, can also be a line of text) moving along the specified trajectory, resulting in a simple animation effects. According to this idea, the animation can be summarized into 3 types: frame based animation, character based animation, object animation. animation based frame; frame based animation works very much like the previous mentioned flip book, when the fast playback of all the pictures, it will produce a dynamic feeling of running. Initially, people in the computer to imitate the original animation technology, you need to manually draw each frame image, the production efficiency is very low. Now, with the rapid development of computer technology, the use of advanced animation software, you can cut, copy, paste and other ways to reduce duplication of labor, improve the speed and quality of animation production. In addition, the editing of each frame is much more relaxed than before. Animation based role, which 
is based on the role of the animation is based on the frame of the animation technology evolved, the purpose is to improve the speed of animation production. The name comes from a hierarchical technique, an animation technique that is superimposed on a static background. By using this technique, the animation maker does not need to re draw all the elements of each frame in the animation. For example, in a scene in the animation, the background only needs to be generated once, and then by moving objects in the foreground to produce animation. And frame based animation, in the role of animation, but also pay attention to the performance of the prospect of action. Each movement and posture must be subdivided into basic components, and then carefully draw down. Obviously, using a public static background can improve the efficiency of the process.

\section{References}

[1] LuoZhe. Chinese Contemporary Animation Education Reflection .The Group Article Heaven and Earth [M]. 2011.

[2] Wu Chunyuan. Analysis China's Animation Education in Colleges and Universities. Intelligence $36,2010$.

[3] Jia Fou, Lu Shengzhang. Introduction to animation [M]. Beijing: the communication university of China Publishing House, 2005.

[4] Annual report for animation industry group. Annals of the animation industry $\quad[\mathrm{M}]$ Ocean Press, 2006.

[5] Qin Xijie. Chinese animation industry economics research [M]. Beijing: China Publishing House, 2006. 